\title{
Examining the Relationship Between School Facilities and the Learning Environment: A Case Study of Oda Senior High School
}

\author{
Samuel Nyamekye Otchere ${ }^{1^{*}} \quad$ James Badu Afari ${ }^{2} \quad$ Christiana Kudawe ${ }^{3}$ \\ 1.Methodist College of Education, Akim Asene, Aboabo-Oda \\ 2.Agogo Presbyterian Women's University College of Education \\ 3.Wesley College of Education, Kumasi
}

\begin{abstract}
The purpose of this study was to examine the relationship between school facilities and the learning environment in Oda Senior High School in the Birim Central Municipality in the Eastern Region of Ghana. The intent of this research was to determine how school facilities affect the students' learning environment and academic performance.A descriptive survey research design was adapted where a total sample of 20 students, 10 teachers and 1 main headmaster and 3 assistant headmasters were selected for the study. The data was collected using questionnaires for the students and teachers as well as interview guides for teachers and head teachers and finally observational guide was used by the researcher. This study used descriptive statistics to analyze the data. The results of the data analysis findings indicated that quality and educational adequacy of educational facilities were significantly associated with student learning environment and academic performance. Based on these findings, it was recommended that The Ministry of Education should provide adequate funding for school facilities. This would ensure their effectiveness in terms of acquiring facilities flexibly and responding to schools' demands quickly. In addition, in order to handle school facilities effectively, school heads and teachers need to be proactive. For example, they should exhibit maintenance culture.
\end{abstract}

Keywords: School facilities, Learning environment, Academic performance.

DOI: $10.7176 / \mathrm{JEP} / 10-26-02$

Publication date:September $30^{\text {th }} 2019$

\section{Introduction}

Many of our nation's students attend schools that are old, outdated, uncomfortable and even unsafe. According to Lewis, Neill \& David (2000) the satisfaction with school environmental conditions, including lighting, heating, ventilation, indoor air quality, acoustics or noise control, and physical security of buildings enhance students morale in learning. Kennedy \& Agron (2004). Argued that effective school facilities positively affect educational environments to ensure that they enhance teaching and learning, while providing safe, healthy, and comfortable schools. Education is the bedrock for the development of every nation. It is thus responsible for human resource development of a nation. In view of this, the Article 25 (1A) of the 1992 Constitution of Ghana makes provision for basic education to be free, compulsory and be made available for all children of school going age in the country. This constitutional requirement is aimed at laying a strong foundation for education at basic levels which will in the long run move the country to a middle-income status by the year 2020 (Ghana Vision 2020). To achieve this aim, teachers in the various subject areas strive hard to ensure that their students successfully pass with little or no hindrance, which is also the wish of parents and the society. It is also their wish that their students understand the content that will be taught. This is because the understanding of the content taught will help in the attainment of the objectives of the lesson. The impact of education on national development is acknowledged worldwide. Governments believe that investing in the training of their people will help in the growth of their nations (Rebore \& Stollenwerk, 2001). As people learn new skills and acquire new knowledge, they contribute positively to nation building. According to Rusk (1987), Plato saw education as a tool for bringing each person to develop a sense of duty to fulfilling his respective functions of the state. Plato again asserted that education leads a person from the enclave of darkness of ignorance into the limelight of knowledge (Akinpelu, 1981).

Education plays an instrumental role in enhancing human capabilities and achieving objectives of economic development. It is used as a vehicle of nation building. In this way, the education sector is a very important sector. Decisions about providing resource inputs to the education sector are made; however, not all these decisions are easy to take, especially in the third world countries like Ghana where mismanagement makes the problem more adverse. As Tan, Lane \& Coustere (1997) remarked. "Resources are scarce, especially in lowincome countries; policy makers can ill afford errors in the choice of allocations. To reduce the scope for mistakes, the true picture of the determinants of education outcome is desirable". (p. 857). Educational facilities are the determinants of education outcome and are of many kinds such as institutional resource inputs. All these resource inputs are the factors of student achievement. However, all these school facilities are not well managed by the school leaders (Schneider 2002). In his work, (Filardo, 2008) also added that the situation of school facilities are of old age, it affected the school environment which in turn affect the students' academic 
performance. This situation is not different at the study area. An educationist directly deals with and controls these school facilities to enhance the school climate and to influence students' academic performance and behavior. This study deals with school facilities in general and their relationship with the school climate or environment.

Lyons (2001) contended that learning was a complex activity that supremely tested students' motivation and physical conditions. Teaching resources, teachers' skill, and curriculum played a vital role in a child's education. Educators must realize that there were many elements that influenced the condition of the school facility. These elements could range from educational leadership to community involvement. There was no one element that operated in isolation (Lyons, 2001). Educators needed to be informed about the conditions of their school facilities as well as appreciate the differences that facilities could make in helping to educate their children.

Many schools face many challenges of out-of-date design and facilities, deteriorating conditions, and changing utilization pressures (overcrowding and declining enrollments). These deficiencies impaired the quality of teaching and learning that contributed to health and safety problems for staff and students (Vincent \& Filardo, 2008).

Although students spend a lot of time in schools and their academic achievement and behavior can be affected by the condition of their schools, Stake (1999), states that "schools are good for children, but schools cannot overcome deep deficits" (p. 668). In essence, it is important to recognize that students are a sum of their experiences and they are also heavily influenced by other factors which cannot be controlled by schools. Some of these factors include but are not limited to the "economic status of students, parent literacy, and parent attitudes towards education" (Paredes, 1991, p. 1) Stake (1999) further adds to this list to include "infant nurturing, sibling rivalry, early childhood experiences, peer inactivity, exposure to language and word games, and television" (p. 668).

With all these inputs, one may wonder how much of an effect school facility have on behaviour, school climate or environment and academic performance. A study conducted in Virginia revealed "cosmetic building conditions . . . are more significant in terms of behaviour than structural building condition" (Abramson, 2001, p. 83). As discussed earlier, structural issues can cause student absences due to sustained injuries out of the use of these facilities.

Kozol (1991) has long been a leading voice on the issue of the conditions of school buildings and facilities. In 1991, he published his book Savage Inequalities: Children in America's Schools, in which he painted a vivid picture of the abysmal conditions that prevailed in many urban school facilities. In an effort to address the condition of school facilities, American School and University magazine issued a series of reports titled "Facilities Impact on Learning." The first installment was published in February 1992 and included an interview with Kozol, In the interview he stated that". . . when the roof is caving in, when the light fixtures are exposed, when the sewage leaks, when the rain comes in through the roof; . . . his tells the children in the eyes of society, 'You are nobody at all'" (as cited in Kennedy \& Argon, 2004, p. 22-23).

According to Nigaglioni, (2005), "students spend an average of 13,000 hours of their lifetime in a school" (2005, p. 7). With so much time spent in the classroom, it is no wonder why some people believe that the condition of school facilities has an impact on student achievement and behavior. In fact a study showed that, when exposed to natural lighting, students "progressed 20 percent faster on maths tests and 26 percent faster on reading tests in one year" in comparison to students who learned in classrooms lit by artificial lights (Bently, 2004, p. 10).Lost time can be a significant factor in a school facility's effect on student achievement and behavior.

In two calendar years, the Commonwealth of Virginia recorded a total of 96 days lost because school districts made the decision to close on account of hot weather conditions and there were an additional 44 occasions of early dismissal due to the rise in temperature during the school day. Of course, these figures could be higher because they do not take into account days when schools remained open despite the fact that teachers and students were uncomfortable (Duke, Griesdorn, Gillespie \& Tuttle, 1998, p. 3).

There may be those who attended school in the days before the advent of air conditioned schools who argue that air conditioning is not a necessity; however, studies show that "temperatures above 80F degrees tend to produce harmful physiological effects that decrease . . . work efficiency and output" (as cited in Jones, 2002, p. 31). A science project conducted by Ms. Fizzle's class showed that classroom temperatures in the building fluctuated between the $60 \mathrm{~s}$ and 98 degrees. She wondered "how can anyone expect excellence of teachers and students when we work under conditions like these?" (Comforts, 2005, p. 43).

Other factors which result in lost days for schools include issues with electrical problems, water, sewerage, and boiler failures. However, not all issues affect the entire student body. Sometimes a roof may leak in isolated areas and the school will remain open. The leaking roof may become distracting to students or the class may be moved to another area of the building. Other incidents of lost time affect individual students. These come in the form of student absenteeism as a result of allergies caused by contaminants in the building, poor ventilation, and 
may even include severe injuries suffered from falling though a rotten floor (Duke, et al., 1998, p. 8).

In essence, the simple explanation is "the more time students are exposed to instruction, the more likely they are to learn." (Duke, et al., 1998, p. 2) School facilities in poor condition can impact education by keeping students away from the classroom thereby decreasing the classroom time. It is commonly believed that the physical condition of a learning environment can impact student achievement. However, due to the multiple factors which also influence education, there are few studies to support this common opinion. Wyoming is one of the few states that maintain a database containing information on the condition of all school facilities in the united states. For that reason, Glenn, Picus, Marion \& Calvo (2006) selected Wyoming for a correlation study to determine whether there is a correlation between school conditions, student achievement and behaviour.

After completing the correlation study, which controlled socio-economic status of students, to determine the correlation between the condition of school building and a three year average of student achievement and behaviour based on results of proficiency tests and scale scores, the researchers determined that there was [no significant correlation. . . between building Condition Scores and Proficiency Test Scores." The authors concluded that money spent on improving school conditions "could have been better spent if the objective was to improve student achievement." However, at the same time they also stressed the importance of having a safe environment in which students can learn in (pp. 15-16).

A study of schools in England showed that although "teachers have had to work in second rate facilities for too long," there is in fact a law of diminishing return when it comes to improving facilities. Inexpensive improvements such as improvements to lighting, paint schemes and new classroom furniture can improve student achievement and behavior while more costly improvements will not improve the student achievement and behavior enough to justify the expense (Paton, 2005, p. 18). A common trend at the time was for schools to organize motivational speeches featuring popular athletes or political leaders who share a common background with the students. The speeches typically focused on the phrase "you are somebody." One wonders what speaks louder, the speech or the condition of the schools. Kozo (1991), states that the answer is obvious; the condition of the school speaks louder and the students know where they stand in the eyes of society (Kennedy \& Argon, 2004, p. 23).

In a critical study carried out by the Ghana Education Service (1999) sponsored by UNESCO. It was identified that school facilities and resources like workshops, classrooms, laboratories, libraries, administration blocks, stores, dormitories, dining halls, equipment and competent personnel as well as teachers are seriously lacking in almost all the secondary, technical and vocational institutions in Ghana. In his book Principles and Practice of Education, Vincent \& Filardo (2008), explains learning as the process by which we acquire and retain attitude, knowledge, understanding, skills and capabilities that cannot be attributed to inherited behavioural pattern or physical growth. He also defines teaching to mean a process that facilitates learning for a relatively permanent change in behaviour of the learners. Vincent \& Filardo (2008), briefly states that these two processes can best promote education in an atmosphere in which this qualitative and quantitative availability of good teaching and learning environment or climate is needed in our educational system.

Many authors have argued that school facilities play important role in the quality of education and the school environment or climate. School facilities can either be teaching or learning resources. School facilities are those materials available to the teacher and student in an educational setting, which he or she uses to make his or her teaching and learning process more meaningful and effective for his or her students understanding. Tamakloe, Amadahe \& Atta (1996) explains school facilities as any material which a teacher uses to facilitate learning, understanding or acquisition of knowledge, concepts, principles and skills to his students; hence those resources could be referred to as teaching and learning resources. In other words, these teaching and learning facilities are what the teachers use to make learning easier.

School facilities can be classified into three (3). They are: visual, audio and audio - visual or multi-sensory materials (Nacino-Brown, Oke, \& Brown,1982). Casciem \& Roney (1998) opine that school facilities are either visual or audio aid. This classification is also supported by Aggarwal (2001), who says that school facilities are visual, audio or audio visual. These resources can be said to be grouped mainly in visual (seeing) audio (hearing) and audio- visual (hearing and seeing). Visual aids are materials or resources that transmit information which could be coded or decoded by the use of the sense of sight (seeing). They are materials to be viewed, observed and then interpret the facts therein. They may be real, concrete objects, or print materials such as text books, newspapers, and magazines. The visual materials provide vast quantities of information on the world and its operation. In teaching, they should be made very attractive to the extent that they can attract the student's attention so that they would tend to look at it very closely.

Audio material resources are those educational resources whose information can only be decoded by the sense of hearing; they include the gramophone, radio, audio tape, drums, public address system (PAS) in the classroom, and the pitch of the speaker or the sound which denotes clarity of the voice which should be considered. Audio visual materials are these that appeal to both the sense of hearing and seeing (sight) they are instructional devices that help the teacher to clarify, establish and co-ordinate accurate concepts interpretation 
and application which enable him or her to make learning concrete, effective, interesting, inspirational, meaningful and vivid. (Aggarwal, 2001). This is why they may be referred to as multi- sensory. They have added advantage because the students will learn from seeing and hearing from the same form of materials. Aggarwal (2001) identifies some of the materials to include films, printed materials with recorded sounds, television, video tapes, sound, film strips, and study strips.

From the above, various authors have attempted to identify an endless list of categories of educational or instructional resources. For instance, Parker (2001) classifies educational resources as "reading" and "non reading" resources. The reading resources include text books and other printed materials. Non reading resources cover all other materials that are used such as buildings, pictures, television, videos, etc.

\subsection{Statement of the Problem}

According to Edwards (1992), research studies had been consistent in describing poor conditions of schools and raising concerns about the effects of school facilities on teaching as well as learning environment. The poor condition of some schools raised serious concerns about teacher and student safety. When providing quality equitable and efficient education for students, stakeholders must take into consideration the role school facilities had played in the educational and learning environment. Headmasters must understand and find ways to help increase student performance. Therefore, headmasters, teachers, parents and Educational authorities must understand the relationship that existed between learning environment and school facilities.

\subsection{Objectives of the Study}

The researcher aimed at achieving the following objectives:

1. To describe the educational facilities available in the school (i.e. Oda SHS)

2. To examine how the school facilities are used in (Oda SHS)

\subsection{Research Questions}

The study will be guided by the following research questions:

1. What are the various school facilities in the school (i.e. Oda SHS)?

2. How effective are the school facilities used in the school (i.e. Oda SHS)?

\subsection{Significance of the Study}

Dewees (1999) activated a renewed interest in the condition of educational facilities nationwide. He found that there were a high number of inadequate buildings and other school facilities. Dewees (1999) further noted that the primary purpose for school facilities should be to provide a quality educational environment for teaching and learning. Provision for proper care and maintenance of school facilities should be provided at all times. The researcher believes that stakeholders of education must ensure that all students should receive the chance for quality education in facilities that are safe, well-equipped, and sufficiently maintained.

This research study was significant in exploring the relationship of the school learning environment and school facilities. Educational leaders must support reforms that helped to increase student performance. Educational leaders must understand the relationship that existed between learning and school facilities. Identifying specific factors that contributed to the learning and educational environment was significant in helping headmaster and his assistants, planners and teachers to prioritize what areas of the learning and the educational environment process led to a quality education for all students in the Oda senior high school. Information that was gathered from this research study will be useful for stakeholders and teachers in planning and making decisions about future funding for facilities. Specific needs were often unknown. However, there was a need for equitable facilities improvements in the Oda senior high school.

\section{Theoretical Perspectives of Student Achievement and School Facilities}

Educational facilities play an important role in the academic development and behaviour of students. In view of the above, governments and school authorities make efforts to provide acceptable levels of educational facilities to enhance teaching and learning in their schools. The link between educational facilities and students' behaviour and academic performance is not in doubt. Edwards (1992) found in his study that school facilities such as buildings had an effect on student achievement. Cash (1993) found significant differences in the achievement scores of students in schools with standard, substandard, and lower standard facilities in the United States. Comparatively, the schools with lower standard of school facilities recorded low academic achievement scores. This implies that senior high schools with low facilities usually achieve little in terms of academic achievement. This study determined the nature of school facilities in Oda Senior High School and whether the academic standard they had achieved over the years was influenced in anyway by the facilities they have.

School authorities would improve the educational opportunities of their students by ensuring that facilities are in good condition in order to provide the best possible learning environment. This is in line with research 
findings that show a strong relationship between school facilities and students' behaviour and academic performance (Phillip, 1997). Good and adequate facilities would enhance teaching and learning in senior high schools in the country especially Oda Senior High School.

According to Lackney \& Picus (2005), school facilities should be responsive to the changing programmes of educational delivery. In addition, school facilities should provide an environment that is safe, secure, comfortable, accessible, well-ventilated, well-illuminated, aesthetically pleasing, and should be an integral component of the conditions of learning. This implies that it is not just providing the facilities but those that will be responsive and appropriate to the needs of the academic programmes of the students in the school. It is expected of school authorities to provide leadership in that direction.

\subsection{Physical Environmental School Conditions}

The senior high students just as the schools they attend desire to attain high academic standards. The students therefore expect the school authorities to provide quality facilities that will give them a sense of belonging, fulfillment and satisfaction in their studies. The desire for high educational attainment calls for good academic environment. Abraham (2003) posited that the type of atmosphere required for effective teaching and learning consists of better school buildings and other teaching facilities. Again, Abraham concluded that "the quality of education that our children get bears direct relevance to the availability or the lack of physical facilities and overall atmosphere where the learning takes place (2003:160).

Students are not the only individuals affected by poor school facility such as quality buildings. Teacher behaviours and attitudes have also been linked to the quality of school facilities (Uline \& Tschannen-Moran, 2008). A myriad of factors affect teacher retention, but most teachers work in a specific physical facility (the school building) and the quality of that building has an impact on teacher morale, the ability of teachers to teach, and the health and safety of teachers (Buckley, Schneider, \& Shang, 2004). It is expected that the school facilities in the country might not be in good state due to our poor maintenance culture.

Buckley, Schneider \& Shang (2004) surveyed 835 teachers. The results of the study found that the quality of school facilities is an important predictor of the retention/attrition decision of teachers. The teachers were asked to indicate whether they planned to remain another year in their current school. The researchers concluded that as the perceived quality of the school facilities improved, the probability of teacher retention also increased.

Thermal comfort within a building is another area in which research has linked school facilities to teacher performance. Lackney (1999) showed that teaching quality and student achievement is linked to teachers' beliefs about thermal comfort. Lowe (1990) found that best teachers mostly emphasized their ability to control classroom temperature as central to the performance for both teachers and students.

Lighting in the classroom impacts positively on students' performance (Phillips, 1997; Heschong Mahone Group, 1999; Jago \& Tanner (1999) on their part suggested that appropriate lighting plays a significant role in the achievement of students, improves test scores, and reduces off-task behaviour. It is interesting to note that Buckley, Schneider \& Shang (2004) reported that the lighting in their building was inadequate and over $20 \%$ of the teachers could not see through the windows in their classroom. Lighting is an important factor for student achievement; teacher morale could be impacted by the lack of lighting in the school facility (Heschong Mahone Group, 1999)

\subsection{Challenges in Schools Facilities}

The basic objective of senior high school education in preparing students for higher education and the world of work is hampered because of poor educational facilities. Poor school facilities make it difficult for teachers to instruct their students, and also increase the probability that teachers will leave their school and the teaching profession. Myriad factors clearly affect teacher retention and performance, but most teaching takes place in a specific physical location (a school building) and the quality of that location can be affected by the ability of teachers to teach, teacher morale, and the very health and safety of teachers (Jago \& Tanner, 1999).

Another factor impacting negatively on the quality of school facilities is poor indoor air quality in the schools which in turn affect teacher working conditions and student achievement. Student absenteeism increases and student performance reduces in such buildings (Leach, 1997). The health of teachers is also affected because of the poor indoor air quality of schools and this could lead to teachers losing considerable instructional time which will eventually affect the students' academic work (Buckley, Schneider, \& Shang, 2004). Lowe (1990) found that the best teachers emphasized their ability to control classroom temperature as central to the performance of both teachers and students

Earthman and Lemasters (1997) emphasized that higher student achievement is associated with schools that have less external noise. Outside noise causes increased student dissatisfaction in their classrooms, and that excessive noise causes stress in students. Teachers also attach importance to noise levels in classrooms and schools. Lackney (1999) found that teachers believe that noise impairs academic performance. Indeed, it appears that external noise causes more discomfort and lowered efficiency for teachers than for students (Lucas, 1981). 
Moreover, school heads and other educational leaders focused more on the curriculum and pedagogy rather than the actual physical environment (Sanoff, 2001). It is important for school administrators to have a basic understanding of facility assessment and use this knowledge to evaluate the condition of school facilities and its impact on students' success (Maiden \& Foreman, 1998; Lackney, 1999; Sanoff, 2001).

\subsection{School Climate and the Learning Environment}

Marshall (2009) explained that school climate affects many areas and people within schools. School climate played a significant role in providing a healthy and positive atmosphere (Marshall, 2009). The physical structure of a school building and other facilities and the interactions between students and teachers, the characteristics of schools, were two diverse factors that affected and helped to define the broad concept of school climate (Marshall, 2009).

For many years, research on school climate had shown and had continued to be examined and redefined as a result of its significant influences on educational outcomes. Kupermire, Leadbeater, Emmons \& Blatt (1997) found that a positive school climate was associated with behavioural and emotional problems for students. Haynes (1998) found that positive school climate perceptions were factors for boys and may supply high-risk students with a supportive learning environment. McEvoy and Welker (2000) found that positive school climate, interpersonal relationships, and optimal learning opportunities for all students could increase achievement levels and reduce disruptive behaviour in students.

Manning and Saddlemire (1996) on the other hand concluded that all aspects of school climate that included 'trust, respect, mutual obligation and concerns for others' welfare can have powerful effects on educators' and learners' interpersonal relationships as well as learners' behaviour, academic achievement, and overall school progress" (p. 41).

\subsection{Learning Environment and School Facilities}

The concept of "learning environment" will become increasingly significant as schools of the future become centers of lifelong learning. "Learning environment" is a term used liberally in educational discourse because of the emerging use of information technologies for educational purposes on the one hand, and the constructivist concept of knowledge and learning on the other (Mononen- Aaltonen, 1998). The OECD (2006) defines "educational spaces" as "a physical space that supports multiple and diverse teaching and learning programmes and pedagogies, including current technologies; one that demonstrates optimal, cost-effective building performance and operation over time; one that respects and is in harmony with the environment; and one that encourages social participation, providing a healthy, comfortable, safe, secure and stimulating setting for its occupants".

In its narrowest sense, a physical learning environment is seen as a conventional classroom and, in its widest sense, as a combination of formal and informal education systems where learning takes place both inside and outside of schools (Manninen et al., 2007). Manninen criticised traditional school teaching for conveying too much theoretical information and for preventing in-depth learning. He claims that inert knowledge is relevant for exams but not for real-world problems. This idea is posing new challenges and exerting pressure to bring about changes in physical learning environments. The concept of the physical learning environment with respect to physical structures relates to spaces, equipment and tools within the school. Lehtinen (1997, p. 21) suggests that the concept has evolved into an even more complex structure that includes teaching equipment, sources of information and events outside of schools, where students can take part in the learning process both directly and virtually.

The term evolved as a result of the recent changes taking place in pedagogy, whereby actual learning has been transposed outside of schools thanks to developments in communication and information technology. Internet has already brought about significant changes in schools. Both the immense quantity of information available and easy access to social networks have weakened the link between schools and learning and therefore modified the traditional teacher-student scenario. The learning process is becoming more co- operative, changing the teacher into a learner too. Manninen (2007, p. 27) categories learning according to five different contexts: physical, local, social, technological and didactic. The basic structure of teaching spaces does not seem to have evolved much over the past century. This fact inspired the research team to investigate the reason why, despite the recent changes in pedagogy and the widespread use of information technology inside classrooms and school spaces, the physical learning environment has not yet changed in keeping with this evolution.

In order to plan and construct effective physical learning environments, not only technical specifications need to be elaborated; qualitative aspects also need to be considered (Nuikkinen 2009, p. 64). The concept of "quality design" has become critical the world over. It relates to school construction and, more particularly, defining a quality physical learning environment, measuring it and analyzing the results (OECD, 2006). With regard to quality criteria for school building and design, the key actors are students; requirements are determined by specific age groups, in conjunction with societal needs and regulations relating to usability and safety (Heitor, 
2005). It has been demonstrated that international comparisons of education can be achieved through comprehensive quality management and quality criteria (Finnish National Board of Education, 2008; OECD, 2006). As a result, the emphasis is shifting from developing physical learning environments using norms and regulations to comparing these environments on the basis of qualitative improvement (OECD, 2009).

According to Sanoff $(2001$, p. 4) "Unhealthy and unsafe school conditions make it difficult for students to concentrate, for teachers to teach, and for staff to do their jobs" (p. 5). In the United State, school conditions led to lower student attendance and reduced teacher and staff retention, at a time when testing requirements make attendance more important than ever and retaining good teachers was seen as a key ingredient in raising student achievement.

Sanoff (2001, p. 4) further reported that providing a healthy environment was actually making schools conducive for learning. Everyone was being held accountable for improved academic performance, the teachers, the students, and the schools. However, if the school facilities were inadequate, it became extremely difficult for academic performance to improve. Sanoff (2001, p. 4) discussed some categories that effected the learning environment:

1. Air quality - poor air quality caused illness, illness such as asthma and other illnesses that caused students to have difficulty in concentrating and lower achievement;

2. Noise-poor acoustics in classroom that caused classroom disruption and outside sounds; and (c) overcrowding - increased discipline problems, distractions, and too many students.

Chan (1996) suggested that a school facility was a school building that accommodated instructional activities. Therefore, the design of a school building needed to reflect the instructional needs of the school. School facility planners and headmasters had to make modifications to existing facilities (Chan, 1996). Renovation at the schools ensured that facilities were brought up to safety standards (Klauke, 1988). Smith (1984) pointed out, "Facilities should further the academic standards of the school: if they are inadequate or inaccessible, the academic programme cannot be wholly successful" (p. 3). Special rooms in the school building needed to be assigned and modified to serve the handicapped situation. Other educational elements that impacted the school environment and school facilities included: school enrollment, grade classification, space utilization, instructional equipment, extracurricular activities and management changes (Chan, 1996, p. 10). Every time changes were made to these educational elements, appropriate modification to the school facility would be needed (Chan, 1996).

\subsection{Characteristics of High Performing Schools}

Chan (1996) reported that high performance schools were schools with facilities that improved the learning environment while saving energy, resources, and money. The key was to understand the lifetime value of highperformance schools and effectively managing priorities, time, and budget during the design and construction. High performance schools referred to the physical facility - the school facilities and grounds. Good teachers and motivated students could overcome inadequate facilities and perform at a higher level almost anywhere, but a well-designed facility could truly enhance performance and make education a more enjoyable and rewarding experience (Smith, (1984).

In order to boost the students' academic performance, Smith (1984) emphasized on the following nine characteristics that should be embedded in all stages of the school planning process: (a) clear and shared focus; (b) high standards and expectations for all students; (c) effective school leadership; (d) high levels of collaboration and communication; (e) curriculum, and instruction, and assessment aligned with standards; (f) frequent monitoring of learning and teaching; (g) supportive learning environment; and $(\mathrm{h}$ ) high levels of family and community involvement.

Chan (1996) on the other hand reported that a healthy high performing school: (a) improved student academic performance, (b) promoted student and staff health, (c) supported healthy lifestyle choices among students and staff, (d) was cost effective and lowers a building's operating expenses, (e) reduced a building' environmental impact and served as a good neighbour, and (f) created a centerpiece for the community. A healthy, high performing school provides a productive learning environment for students and staff, promoted a healthy lifestyle, save operating costs and help sustain the environment. Healthy, high performing school facilities had a positive effect on student learning (Chan, 1996)

\subsection{Workforce Sizing Plan (WOZIP)}

Job-shop production refers to a manufacturing environment that produces goods in small batches according to customer specifications. Usually, one or several types of products are deliverable, while the incoming orders may differ in the design, quantity, process flow, or urgency (Henrich 2005). Flexibility is allowed in terms of switching between machines, methods, and resolving problems in production. Depending on the nature of business, each of the workers hired may need to possess a certain range of skills to handle different tasks or machines, whereas the total number of workers may be adjusted in response to the varying demand. In practice, 
transferability of permanent workers and recruitment of temporary or contract workers will help make such adjustment feasible, thus admitting of the idea of WOZIP.

\subsection{RESEARCH DESIGN}

The design of this study was basically a descriptive survey, followed by a qualitative model with the intent to answer the study research questions. The descriptive survey attempts to describe some aspect of a population or an existing phenomenon by selecting unbiased sample of individuals to complete a questionnaire and take part in interviews (Strauss and Corbin, 1990). Patton (1990) defines bias as inaccuracy of information. According to Steinar (1996), surveys are good for asking people about their perceptions, opinions and ideas, though they are less reliable for finding out how people actually behave. Steinar further stated that this is achieved by creating a questionnaire and collecting responses from a sample, to draw a profile of the group as a whole, and perhaps perform some course-and-effect analysis to understand the source of those feelings.

\subsection{Population of the Study}

The population is the group of interest to the researcher, the group to which he would like the results of the study to be generalizable (Gay, 1992, p. 124). The target population for the study is made up of all teachers, students and headmasters in Central Birim Municipality

\subsection{Sampling Technique and Sample}

Hussey \& Hussey (1997) emphasized on two main sampling techniques namely; probability and non-probability sampling. Probability sampling technique is the sampling process whereby randomness is essential and key element in the process, whiles non-probability sampling technique is based on the judgment of the researcher. Simple random sampling technique was chosen to select 10 teachers, purposive sampling technique was used to select the four head masters and 20 students. In all, 34 respondents participated in the study.

\subsection{Research Instrument}

The study used both primary data and secondary data. The primary data was collected using interviews guides and observation list. Cohen and Manion (1981:307) defines an interview as "a two way process of conversation initiated by the interviewer for the specific purpose of obtaining through research, relevant information and focus on content specified by research objectives of systematic description or explanation." The technique allows greater depth than is the case with questionnaires, that is, there is direct interaction between the researcher and the respondent. The technique reduces the risk of misinterpretation by respondents, since the researcher will have the chance of explaining the purpose of the study and to clarify any queries raised during the interview. The technique also permits the establishments of rapport, confidence and co-operation between the researcher and respondents. This makes it easy for the interviewer to get the information required. The headmaster and his three assistants were interviewed in this study.

Observation checklist was formulated to include information that will lead to conducting the study. Observations were made when the researcher visited the respective school. This helped to ascertain the status of the school facilities and equipments that were used in the school.

\subsection{Structured questionnaire}

Structured questionnaires were used for data collection from teachers and students. These structured questionnaires were chosen because they ensured the confidentiality of responses and saved time. In addition, they are widely used in social science research and education. Asika (1991) writes that $90 \%$ of the research in the social sciences is conducted using questionnaires.

\subsection{School Facility Questionnaire}

School facility questionnaire used for this study was constructed by the researcher. This is a self-report measure items designed to determine the relationship between school facilities and learning environment in Oda SHS. Participants' response to whether each item was present in the school and the use of those school facilities on a 4-item point scale ranging from Strongly Disagree (1), Disagree (2), Agree (3) and Strongly Agree (4). This questionnaire consists of 20 items. In this study, the reliability of school facility Questionnaire was 0.81 .

\subsection{Interviews}

Interview guides are data collection instruments used through direct and verbal interaction between respondents. They involve the question and answer method of data sourcing. More and more data is collected through indepth interviews and probing. Creswell (2003) argues that interview guides are important in sourcing for volumes of qualitative data. Thirty teachers were interviewed with each informant given the leeway to choose the convenient time and venue for the interview. The informants were notified two weeks in advance about the 
purpose of the study and the interviews through letters written and sent to them directly.

\subsection{Data Collection Process}

After permission from the headmaster of the school has been obtained, the researcher personally administered the questionnaires to the study respondents and collected the questionnaire later when he was informed about the completion of the instrument. In addition, the researcher used interview guide to measure the opinion of 10 teachers and 20 students on their perception on the subject under investigation. It was a face to face interview. This was useful for gathering in-depth information on the subject under investigation.

\subsection{Data analysis Procedure}

Maxwell (2005) states that analysis involves the breaking up of data into manageable themes, patterns, trends and relationships. McMillan and Schumacher (2001) state that qualitative data analysis is primarily an inductive process. They further state that inductive analysis means that categories and patterns emerge from the data rather than being imposed on data prior to data collection. Data was analyzed quantitatively and qualitatively. Quantitative data was analyzed by frequency tables and percentages. Frequency tables represent the most commonly used method in presenting data in descriptive research (Merriam, 2001).

Qualitative data was evaluated, classified into logical thematic categories based on the objectives and then coded. Analysis of qualitative data collected using interviews and observations were an ongoing process where emerging themes were categorized based on the research questions. As the research progressed, some of the questions were refined while new ones were formulated to fill in the research gaps detected. Any question arising during categorization was also included.

The analysis of the structured items was done by using the Statistical Package for Social Sciences (SPSS). Unstructured items were analyzed manually along major concepts and themes, and the results were presented using descriptive statistics. Conclusions were drawn from the analyzed data, leading to recommendations and suggestions for further improvements on school facilities.

\subsection{Ethical Considerations}

As this study utilized human participants and investigated on accounting school practices in life, certain issues were addressed. The consideration of these issues is necessary for the purpose of ensuring the privacy as well as the security of the participants. These issues were identified in advance so as to prevent future problems that could have risen during the research process. Among the significant issues that were considered included consent, confidentiality and data protection. In the conduct of the research, the questionnaire was drafted in a very clear and concise manner to prevent conflicts among respondents. People who participated in the research were given ample time to respond to the questions posed on them to avoid errors and inaccuracies in their answers. The respondents were given a waiver regarding the confidentiality of their identity. The respondents' cooperation was eagerly sought after, and they were assured that the data gathered from them would be treated with the strictest confidence, so that they would be more open. This was done with the hope that this would promote trust between the researcher and the respondents.

\subsection{Observation findings}

In observing the school facilities present in Oda SHS, the researchers' first point of call was at the schools computer laboratory to observe a computer class here, it came out that the school has 68 desk top computers mounted for the use of students at the schools computer laboratory out of which 59 are functional with 9 not working. It also came out that two (2) students shared a computer; they sat on long benches with six students on a bench three computers mounted in front of them with the teacher using a lap top and a projector to explain and demonstrate certain practical's lessons to the student. The laboratory has two wall air conditions which are functional and work at the time of visit.

The next place the researcher visited was the class rooms were the researcher observed that there were on the average of 30 students to a class with one to one desk ratio, this was during a social studies lesson for form 2 students. The classrooms were all painted; the classrooms which are well ventilated had lights and ceiling fans which are all functional and have both marker boards and chalk boards for the use of teachers in teaching. In the area of text books, the researcher observed that every student had a text book to him or herself which according to the students they took from the schools bookshop and will return them back to the bookshop at the end of the term, every student had text books in all the core subjects including some electives which they also took from the school stores.

Oda SHS has a library with a seating capacity of 78 , the researcher observed that students went there to do their private studies, and there were students who went there to read news papers daily. The school has also got a large football field and a basketball court which the boarders used after classes to entertain themselves and for their physical education classes. The school has also got separate wash rooms for students and teachers which 
are well kept.

There are two laboratories for practical's one for the home economics and the other for the technical department of the school, these laboratories are furnished with tools and cooking utensils which students used, aside these two, the school has also got big long hall as its science laboratory which is furnished with apparatus for practical's by students.

The school has three buses which are used for the movement of both teachers and students during occasions or functions. It has a well lay out lawns for movement in the school; it is fitted with lighting system all-round the school. It has 28 masters' bungalows for teacher's accommodation. It has 24-hour water system from standing pipes and bore holes. The school has also got a three-story administration block which has offices for the head master and his assistance and other offices for other administrative staff with a car park in front of it. The schools have at its disposal a multipurpose assembly hall and a dining hall, the compound is cleanly kept with dust bins placed at vantage points for rubbish and lovers benches doted at vantage points under trees on the compound and finally the school is well painted which makes it more attractive.

\subsection{Research Questions \\ Research Question One - What are the various school facilities in the school (i.e. Oda SHS)?}

One core specific objective of this study was to find out the various school facilities in the school (i.e. Oda SHS). This objective was deemed important to the extent that it attempted to provide the existing school facilities in the participated school. The four head masters were interviewed and their responses were presented as follows.

Four sub-themes for school facilities were identified to include the respondents understanding of school facilities, the importance of school facilities and school facilities that are in existence in the school.

Sub-Theme 1 - Understanding of School Facilities

All participants understood the term school facilities and provided definitions that consisted of common themes. Most participants defined school facilities using words such as material resources and school structures. Of the 4 head teachers who were interviewed defined school facilities using generalizing concept. Some of the comments made included the following:

Participant 1: I associate school facilities as generalizing. The material resources in the school teachers use to teach the students. Lack of them hinders students' academic performance, because the students lack the practicability.

Participant 2: School facilities are teaching aids such as computer, chairs, table desks library and books available in the school that teaching and learning.

Participant 3: The core factor of school facility is the school building and playground that provide the student for relaxation.

Participant 4: School facilities are the whole school structures including the school environment

Sub-Theme 2 - Importance of School Facilities

The key themes that emerged from the importance of school facilities were grouped into two emergent themes. It enhances:

1. Teaching and learning

2. School Climate and School Culture

\section{Teaching and Learning}

School facilities were critical to the teaching and learning process. The factors responsible for student achievement were ecological - they acted together as a whole in shaping the context within which learning took place. The school facility was an undeniably integral part of the ecological that was in context for learning. The responses provided by participants included the following.

Participant 1: The school facilities had a profound impact on the teaching and learning process as it provides (a) full-spectrum and natural lighting, and (b) the reduction and control of noise.

Participant 2: The flexibility of school facilities such as classroom when provide the enough to accommodate changing learning patterns and methods enhance effective teaching and learning

Participant 3: Sufficiency of a school facility provides good student behavior which breeds good academic performance.

Participant 4: School facility provides the learning environment that has direct and indirect impact on student achievement. A good learning environment freed student from physical distress, made it easy for students to concentrate on schoolwork and, induced students in logical thinking

\section{School Climate and School Culture}

With regard to the important of school facilities on providing good school climate and culture, various responses were provided by the participants. The responses provided by participants included the following.

Participant 1: When stakeholders invest in school facilities, it stood to reason that teaching and learning environments improved. School facilities that are poorly maintained, dirty, unattractive, and unsafe send powerful negative messages to teachers and students. 
Participants 2: School climate provide excellence school environment that affect student behavior negative or positive.

Participants 3: Schools with positive climates were usually places both the staff and students stay in the school. Participant 4: Students typically work harder, achieved more, and gave more meaning to schoolwork in classes where they felt liked, and appreciated by teachers and their peers. A positive school climate had a great impact on student success.

Sub-Theme 3 - School facilities that are in existence in the school

With this particular theme, all of the participants interviewed had similar perception. The school facilities they mentioned included the following: school library, computer laboratory, table and chairs science laboratory, school football field and attractive buildings, toilet facilities. With these facilities, the students who participated in the study revealed that with the exception of school buildings, the rest were poorest state and as such cannot be utilized to its maximum. Some of their comments included the following:

Student: Our computer laboratory is not helping us in our studies because they were too old.

Head master1: In fact, we have lot of school facilities but they give us problems because they are old, particularly our computers and science equipments.

\section{Facility they would like to have if they had the money}

The head masters were asked to identify the facility they would like to have if they had the money. With this question, all of the 4 headmasters who participated in the interview mentioned computers, science laboratory equipments, while students added school library and the introduction of internet in the school. $80 \%$ of the students indicated phone boots in the school. With regard to how these facilities would help improve the school climate and academic performance, the entire student reported that they will enable them to stay in the school and learn.

Research Question two - How effectively are these school facilities used?

Of the head masters in the study $(n=4)$, they emphasized that because of the old nature of the facilities, the facilities were underutilized. Some of their comments were as follows:

Head master 2: Our computers are old and few, we cannot use them regularly.

Student 4: Our teachers do not allow us to use the computers as we preferred because they said the computer are too old to use them for long time.

Head master 3: Poor conditions of school facilities made it difficult for teachers to teach their students or provided an adequate teaching to their students, which affected their academic performance. These poor conditions caused teachers to leave their schools.

This question was designed to determine how useful the facilities were used in the school. The students' responses were categorized and presented in the figure 1 below.

Figure 1

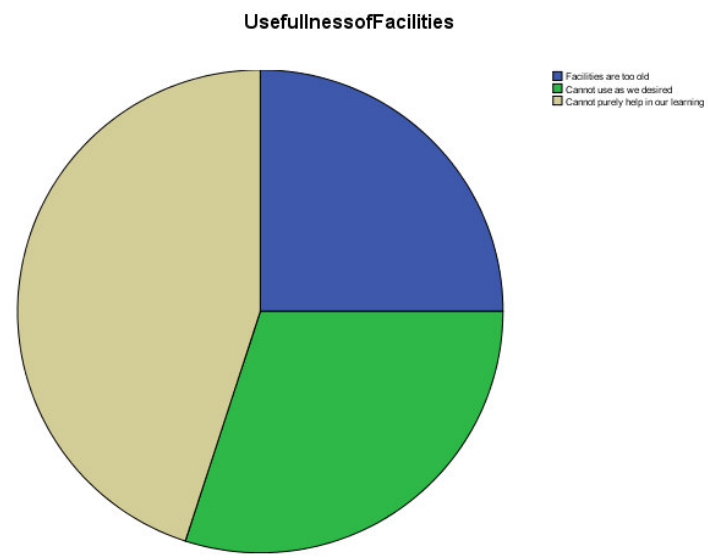

Figure 1: Students perception on the nature of the school facilities

As can be inferred from the figure 1 above, out of the 20 students who participated in the study, 5 of them represented $25 \%$ reported that the school facilities were too old, 6(30\%) indicated that they cannot use the facilities as they desired, whereas 9 of them represented $45 \%$ showed that the school facilities were in position to help them in their studies.

This quantitative result was supported by qualitative responses by some of the students. One of the students who were interviewed stated that: Our library if full of "old old" books and full of dusts. Another student claimed that: We only go to the school library to make ourselves dirty. Another student who was interviewed reported that: We need computers to assist us in our studies but they were of no use to us. She further showed that the computers cannot be used for one hour without a break. In fact, is a worry to us. 
When the students were asked to mention the significance of the school facilities, all of them had a similar view that the facilities can improve the learning and can also make studies easy. One of them stated that: When the school facilities work well, our behaviour and academic performance will be improved. Another student boldly said that: At times we ran to town in searching for internet Café to do our assignment. He continued by saying that if the school has one, we will stay in the school to avoid the consequences.

When the students were asked for the solutions, they all suggested the buying of air conditions will help reduce the frequent breakdown of the school computers.

\section{Conclusion and Recommendation}

School facilities had positive impact on student's academic achievement. This implies that the deteriorate nature of the school facilities negatively hinders excellent academic performance. Schools lacking effective school facilities tend to decreases students motivation towards the ability for attention, concentration and worst, it leads to academic failure. This research finding had found a significant relationship between school facilities and academic achievement among high school students in Oda Senior High School. The present study provides additional evidence for the need to understand more about the effects of school facilities in general and its impact on real-life examinations, particularly as relates to examinations that have significant consequences concerning life outcomes.

The study has discovered that serious deficiencies in school facilities greatly influence the teacher level of job dissatisfaction, thus affecting their performance and productivity. It also discovered that teachers were experiencing problems with the facilities in which they work and are accommodated in as reflected by the results. There is high level of dissatisfaction among teachers with the conditions of their schools' facilities that had resulted in students' indiscipline. There is mounting evidence that school facilities do affect attitudes, behaviors and academic achievements of teachers and students. It is no secret that of late there is a crisis in school buildings. The bottom-line is that a well-designed and well-maintained facility can, and do, make a difference in students' lives and in teachers motivation and morale.

\section{Recommendations}

Depending on the results of the study, the following recommendations can be presented

- School authorities should provide adequate funding for school facilities. This would ensure their effectiveness in terms of teachers output.

- The Ministry should also invests in the school facility expansion. This would assist both teachers to provide enhance professional development services to remote, rural schools and also to boost the students' behaviour and academic environment.

- Communities need to embark on initiatives to tap funds to ensure that the school facilities are replenished.

\section{References}

Abramson, P. (2001).The Demonstrable Benefits of Good School Condition. School Planning \& Management: March, vol. 40 issue 3, p.83.

Abraham, N. M. (2003). Educational Administration in Nigeria. Port Harcourt: Pam Unique Publishing Company Ltd.

Adaralegbe, A. (1983). Secondary Education in Nigeria: Trends, Progress, Problems and Issues in Adesina

Alexander, A. (2008). A Qualitative Exploration of Students' Experiences with Tutorial Learning: "A Doctoral Dissertation", Louisiana State University. Baton Rouge, L.A.

Ahmad, M. (1993). Identification and Analysis of Educational and Socio-economic Factors affecting the

Standards of Education: A Research Study of Secondary Schools in Karachi West and Central Districts. Unpublished PhD Dissertation, Institute of Education and Research (IER), University of Karachi, Pakistan.

Akinpelu, J. A. (1981). An introduction to philosophy of education. Macmillan.

Akinwumiju, J.A. \& Orimoloye, P.S. (1987). Accountability in Public Examination: The Situation in Nigeria (1985 WASC/GCE O-level Examinations). In A. Dada (ed)

Asika, N. (1991). Research methodology in the Behavioral sciences, Lagos: Longman Nigeria Plc.

Ango, M. L. and Sila M.D. (1986). Teaching and Learning of Biology Practical; The Experience of some Nigerian Secondary Schools. Journal of Science Teachers Association of Nigeria, 124(1 \& 2), 33-47.

Antwi, K. A. (1992) Education, society and development in Ghana. Accra. Unimax Publishers Limited Altbach, P.G. (1983). Key Issues of Text book provision in the Third World. Prospects, 13 (315-325).

Aggarwal, P. K. (2001). If I could make a school. Learning \& Leading with Technology, 29, 28-31.

Agron, J. (2009). 35th annual official education construction report. American School University, 81(10), 20-27. Ayeni, A. J., \& Akinola, O. B. (2008). Influence of principals' leadership styles and motivation of teachers on quality assurance in secondary school: A case study of Ondo State. Ife Journal of Theory and Research in 
Education, 2(1-2), 162-170.

Azriel, Z . S. (2002). The impact of a new school facility one districts experience. The faculty of College of

Education, Ohio University.

Ball, S. \& Smith, G. W. H. (1992). Analyzing visual data. Newbury Park, CA: SAGE Publications.

Baker, L. \& Bernstein, H. (2012). The Impact of School Buildings on Student Health and Performance: A call for research.www.mcgraw.hillresearch.foundation.org.

Bano, M. (2007). Pakistan Country Case Study. Country Profile commissioned for the EFA Global Monitoring Report, Education for All by 2015: will we make it? UNESCO, /ED/EFA/MRT/PI/11.

Barone, C. (2006). Cultural Capital, Ambition and the Explanation of Inequalities in Learning Outcomes: A Comparative Analysis', Sociology40 (6): 1039-1058. Cross Ref, of science ${ }^{\circledR}$ times. cited:4.

Bentley, M. (2004). Marking High Performance a reality. School Planning \& Management: February vol.43 issue 2, p.10.

Berner, M. M. (1993). Building conditions, parental involvement, and student's achievement in the District of Columbia public school system. Urban Education,28, 6-29.

Balogun, T.A. (1982). Improvisation of Science Teaching Equipment. Journal of the Science Teachers Association, Vol. 20, No. 2, 72-76.

Beeby, C.E. (1986). The States of Growth in Educational Systems. In S.P Heinemann and D.S. White (Eds). Education and Economic Development Washington, D.C. The World Banks, 37-44

Bly, J. (2007). School climate. From http:www.greendale.k12.wi.us/distirct/news/asset/SNFeb.Bly.pdf.

Bogdan, R. \& Biklen, S. (1998). Qualitative Research for Education: An Introduction to Theory and Methods. Boston: Allyn and Bacon, Inc.

Bond, R. \& Giles, C. (1997). The contracting resource base: a catalyst for educational administration reform. International Journal of Educational Management, 11, 111-116. Retrieved June 9, 2008, from ProQuest database.

Bowers, J. H. \& Burkett, C. W. (1987). Physical environment influences related to student achievement, health, attendance and behavior. CEFP Journal, 26, 33-34.

Bowers, J.H. \& Burkett, G.W. (1987). Relationship of student achievement and characteristics in two selected school facility environmental settings. Edmonton, Alberta, Canada: 64th Annual International Conference of the Council of Educational Facility Planners. (ERIC Reproduction Service No. ED286278)

Berry, B., Smylie, M., \& Fuller, E. (2008). Understanding teacher working conditions: A review and look to the future. Retrieved from http://www.teachingquality.org/pdfs/TWC2_Nov08.pdf

Brown, R. (2009). Virginia's economic and fiscal climate. Retrieved November 17, 2011, from http://www.finance.virginia.gov/VA Asso Assessing Officers 7-15-09.pdf

Bracey, G. W. (2001). Small schools, great strides. Phi Delta Kappan, 82(5), 413-14.

Buckley, J., Schneider, M., \& Shang, Y. (2004). LAUSD school facilities and academic performance. Retrieved My 1, 2008, from http://edfacilities.org/pubs/ LAUSD\%20Report.pdf

Cash, C. (1993). Building condition and student achievement and behavior. Ph. D. dissertation, Virginia Polytechnic and State University, United States -- Virginia. Retrieved July 4, 2009, from Dissertation \& Theses: Full Text. (Publication No. AAT 9319761).

Cawelti, G. (2005). Portraits of six Benchmark schools: Diverse Approaches to Improving Students Performance, Educational Research Service, Report NO.WS-0312,Arligton,VA. Available:www.ers.org.

Chan, T. C. (1996). Environmental impact on student learning. Retrieved May 5, 2008 from http://eric.ed.gov/ERICWebPortal/Home.portal;jsessionid=HwnVGyBDgy9NhJG

H116JTk4TokkyTpywbjQz5r8DFCXHJYqvM1209635? nfpb=true\&ERICExtSearch_SearchValue_0=\%2 2Chan+T.+C.\%22\&ERICExtSearchType_0=au\&_urlType+action\&_pageLabel==ERICSearchResult.

Christopher, G. (1988). The aesthetic environment and student learning. School Business Affairs, 54(1), $26-27$.

Cohen, L. \& Manion, L. (1994). Research Methods in Education. (4th ed.). London: Routledge

Corcoran, Thomas B., Lisa J. Walker, and J. Lynne White (1988). Working in Urban Schools. Washington, DC: Institute for Educational Leadership

Cressell, J. (2003). Research Design: Qualitative, Quantitative and Mixed Approaches. (2 ${ }^{\text {nd }}$ Ed.). Thousand Oaks: Sage.

Conners, D.A. (1982). The School Environment: A Link to understanding Stress. Theory into practice, 22(1),1520.

Carnegie Foundation for the Advancement of Teaching. An Imperiled Generation: Saving Urban Schools. Princeton, New Jersey: Author. ED 293940.

Creature, C. (2005). Education Week; November, vol. 25 issue 11 p. 43.

Darling-Hammond, L. (2000). Teacher quality and student achievement: A review of state policy evidence. Education Policy Analysis, 8(1). Retrieved February 20, 2009, from http://epaa.asu.edu/epaa/v8n1.

Das, R.C. (1993). Educational Technology: A Basic Text. New Delhi: Sterling Publishing Private Limited. pp. 
39-59.

Deal, T., \& Peterson, K. (1999). Shaping school culture: The heart of leadership. San Francisco, CA: JosseyBass.

Dewees, S. (1999). Improving rural school facilities for teaching and learning. (ERIC Digest). Charleston, WV: ERIC Clearinghouse on Rural Education and Small Schools. (ERIC Document Reproduction Service No. ED438153). Retrieved May 21, 2008, from http://www.ericdigests.org/2000-4/rural2.htm

Dawson, C. and Parker, J. R. (1998). A descriptive analysis of the perspective of Neville High School teachers regarding the School renovation. New Orleans, LA: Paper presented at Mid-South Educational Research Association, ED 427506

Duke, D. L. Griesdom, J., Gillespie, M. \& Tuttle, J.B. (1998). Where Our Children Learn Matters: A Report on the Virginia School Facilities Impact Study. Charlottesville; University of Virginia,

Earthman, G. I. (1996). Review of the research on the relationship between school buildings, student achievement, and student behavior. Paper presented at the Annual Meeting of the Council of Educational Facilities Planners, International Tarpon Springs, FL.

Edwards, M. (1992). Building conditions: Parental involvement and student achievement in the D. C. public school system. (Masters Degree Thesis, Georgetown University, ED 264 285, 1992).

Earthman, G. I., \& Lemasters, L. (1996). Review of research on the relationship between school buildings, student achievement, and student behavior. Paper presented at annual meeting of the Council of Educational Facilities Planners, Dallas, Texas.

Earthman, G.L. (2002). School Facility Conditions and Student Academic Achievement: Los Angeles, CA: UCLA's. Institute for Democracy, Education \& Assess (IDEA). 6.

Ekundayo, H. T. (2008). School facilities as correlates of student's achievement in the affective and psychomotor domain of learning. European Scientific Journal March edition. vol. 8, No.6 ISSN: 1857 - 7881 (Print) e ISSN 1857- 743. Department of Educational Foundations and Management, Faculty of Education, Ekiti State University.pp.1-55.

Farrant, J. S. (1980). Principles and practice of education. London, England: English Language Book Society.

Farrant, W., \& Taft, A. (1988). Building healthy public policy in an unhealthy political climate: a case study from Paddington and North Kensington. Health Promotion International, 3(3), 287-292.

Finn, J. D. and Achilles, C. M. (Summer,1999). Tennessee's class size study: Findings, implications, misconceptions. Educational Evaluation and Policy Analysis. 21(2), pp 97-109

Fuller, B. (1985). Raising School Quality in Developing Countries: What Investments Boost

Fisher, K. (2005). Research into Identifying Effective Learning Environments. http:// www.oecd.org/edu/ country studies $37905387 . p d f$.

Fisher, K. (2000). "Building Better Outcomes. The Impact of School Infrastructure on Student Outcomes and Behavior", Schools Issues Digest, Department of Education, Training and Youth Affairs, Australian Government.

Frazier, L. M. (1993). Deteriorating school facilities and student learning. (ERIC Digest, Number 82). Eugene, OR: ERIC Clearinghouse on Educational Management. (ERIC Document Reproduction Service No. ED356564).

Farombi, J.G. (1998). Resource Concentration, Utilization and Management as Correlates of Students' Learning outcomes: A study in School Quality in Oyo State. Unpublished Ph.D. Thesis, university of Ibadan.

Fowowe, S.O. (1988). Finding Academic Libraries in Nigeria: A survey of some Nigerian University libraries. Ilorin Journal of Education, Vol. 8, (21-16).

Fernandez, Ricardo R. and P. Michael Timpane (1995). Bursting at the Seams: Report of the Citizens' Commission on Planning for Enrollment Growth. Office of the Chancellor, New York City Board of Education, 110 Livingston Street, Brooklyn, NY 11201.

Fuller, B. (1985). Raising School quality in developing countries: what investments Boost learning (Education and Training series, Discussion paper number (EDT) Washington DC. World Bank.

Gay, L. R. (1996). Educational research: Competencies for analysis and application. Upper Saddle River, NJ: Prentice Hall, Inc

Gana, E, S. (1997). Effects of Using Visual Designed Training Models on the Learning of Mathematics at J.S.S. Unpublished Ph,D. Thesis, University of Ibadan.

Glenn, W., Picus, L. O., Marion, S. F. \& Calvo, N. (2006). School Facility Quality and Student Achievements in Wyoming. School Business Affairs: May vol. 72, issue 5, p.12-16.

Greenwald, R., Larry, V. \& Laine, R.D. (1996). The Effect of School Resources on Student Achievement. Review of Educational Research, 66(3), pp. 361-396. Retrieved February 12, 2007, from JSTOR database.

Hale, O. (2002). Improving performance. American School and University, 75(2), 32-35.,

Heppner, P. P., Kivlighan, D. M., Jr., \& Wampold, B. E. (1992). Research design in counseling. Pacific Grove, CA: Brooks/Cole. 
Haynes, N. M. (1998). Creating safe and caring school communities: Comer School Development Program schools. Journal of Negro Education, 65, 308-314.

Hines, E. (1996). Building condition and student achievement and behavior. Ph. D. dissertation, Virginia Polytechnic Institute, and State University, United States -- Virginia. Retrieved November 8, 2008, from Dissertation \& Theses: Full Text. (Publication No. AAT 9712733).

Haggins, S., Hall, E., Wall, K., Woolner, \& McCaughey, C. (2005). The impact of school environments: A literature review. London, United Kingdom: The Design Council. Retrieved February 23, 2009 from http://www.designcouncil.org.uk/recourses/assets/pdf/publications/the $\% 20 \mathrm{impact} \%$.

Holloway, J. H. (2000). Healthy buildings, successful students. Educational Leadership, 57, 88-89. Retrieved November 6, 2008, from ProQuest database.

Hodges, V. P. (1998). Need for Improvement of Rural School Facilities. June 1.

Honeyman, D. S., \& Sayles, K. (1995). The condition of America's schools. Retrieved September 17, 2008, From http://www.eric.ed.gov/ERICWebPortal/Home.portal

Heyneman, S \& Loxley, W. (1982). The effect of Primary School Quality on Academic Achievement across Twenty-Nine and Low-Income countries. American Journal of Sociology, 1162-1194

Harchar, R. L. \& Hyle, A.E. (1996). Collaborative Power: A grounded theory of instructional leadership in the elementary School Journal of Educational Administration. 34(3), 15-2

Hawk, M. L. (1995). "As perfect as can be devised.": DeRolph v. State of Ohio and the right to Education in Ohio. Case Western Reserve Law Review. p. 679-704

Heitor, T. (2005), "Potential problems and challenges in defining international design principles for school", Evaluating Quality in Educational facilities, pp. 48, OECD/PEB, www.oecd.org/edu/facilities/evaluatingquality

Holt, C. R., \& Smith, R. M. (2002). The relationship between school climate and student success. Arkansas Educational Research \& Policy Studies Journal, 2, 52-54.

Hoy, W. K., \& Miskel, C. G. (1996). Educational administration: Theory, research, and practice. New York, NY: McGraw-Hill.

Howley, C. (1994). The academic effectiveness of small-scale schooling. Charleston, WV: ERIC Clearinghouse on Rural Education and Small Schools. (ERIC Document Reproduction Service No. ED 372 897)

Hunter, M. A. (2006). Public school facilities: Providing environments that sustain learning. Teachers College Columbia University. New York, NY: National Access Network.

Hussey J \& Hussey, R. (1997). Business research. London: Macmillan Press Ltd

Ingersoll, R. M. (2003). Is there really a teacher shortage? Retrieved February 20, 2009, from http://depts.washington.edu/ctpmail/PDFs/Shortage-RI-09-2003.pdf

Jago, E., \& Tanner, K. (1999). Influence of the school facility on student achievement. Retrieved from http://www.coe.uga.edu/sdpl/researchabstracts/visual.html.

Jegede, O. J. Fraser, B. J. \& Okebukola, PA.(1994). Altering socio-cultural beliefs hindering the learning of science. Instructional Science, 22, 137-152.

Kennedy, M., \& Agron, J. (2004). No buildings left behind. American School \& University, 76(7), 20-26.

Jones, E. (2002). School Funding Inequities: A Statistical Analysis Examining the Adequacy of Funding for Capital Outlay in North Carolina Schools. Research for Educational Reform; vol. 7issue 1 p. 24-46

Jones, E. (2006). School Funding Inequities: A Statistical Analysis Examining the Adequacy of Funding for Capital Outlay in North Carolina Schools. Research for Educational Reform; 2002, vol. 7 issue 1 p. 24-46. Johnson, S. M. (2006). The workplace matters: Teacher quality, retention, and effectiveness. Retrieved November 4, 2008, from http://www.nea.org/research/bestpractices/images/wcreport.pdf.

Kozol, J. (1991). Savage Inequalities: Children in America’s Schools. New York: Crown.

Klauke, A. (1988). Repairing and renovating aging school facilities. Retrieved October 25, 2008, from http://www.ericdigests.org/pre-9210/aging.htm

Kirby, N., \& Grissmer, D. W. (1993). Teacher attrition: Theory, evidence, and suggested policy options. Retrieved May 2010 from http://www.eric.ed.gov/ERICDocs/data/ ericdocs2sq1/content_storage_01/0000019b/80/13/3b/36.pdf

Koul, L. (2005). Methodology of Educational Research. Vikas Publishing House PVT Ltd: New Delhi.

Kowalski, T. (2006). The school superintendent: Theory, practice, and cases. Thousand Oaks, CA: Sage.

Kraft, R., Adipah, B.K., Dzinyela ,J .M., Anku, K. Gala, K., Godwin. E., (1995). The tale of two Ghana's: The review from the classroom. Prepared by D.K. Agyeman, J.J. Baku \& R. Gbadamosi, Review of education sector analysis in Ghana 1987-1998 (pp 97-98). Fontenoy: UNESCO.

Kuperminc, G. P., Leadbeater, B. J., Emmons, C., \& Blatt, S. J. (1997). Perceived school climate and difficulties in the social adjustment of middle school students. Applied Developmental Science, 1(2), 76-88.

Kaufhold, J., Alverez, V., \& Arnold, M. (2006, September). Lack of School Supplies, Materials and Resources as an Elementary Cause of Frustration and Burnout in South Texas Special Education Teachers. Journal of 
Instructional Psychology, 33(3), 159- 161. Retrieved from Education Research Complete database

Lackney, J. A. (1994). Educational facilities: The impact and role of the physical environment of the school on teaching, learning and educational outcomes. Milwaukee, WI: University of Wisconsin-Milwaukee, Architecture and Urban Planning Research.

Lackney, Jeffrey A. 1999. Assessing school facilities for learning. Starkville, MS: Mississippi State University Educational Design Institute.

Lackney, J. A., \& Chang, C. (1992). A longitudinal investigation of building condition, educational adequacy and educational outcomes in the Milwaukee public schools. Retrieved May 12, 2009, from $\mathrm{http}: / /$ scholstudio.engr.wisc.edu/mpsinvestigation.html

Lackney, J. A., \& Picus, L. O. (2005). School facilities - Overview, maintenance and modernization of. Retrieved September 15, 2008, from http://education.state university.com/pages/2394/School-Facilities.htm

Lemasters, L. K. (1997). A slynthesis of studies pertaining to facilities, student achievement, and student behavior. Blacksburg, VA: Virginia Polytechnic and State University

Lewis, M. (2000). Where children learn: Facility condition and student test performance in Milwaukee public schools. Scottsdale, AR: Council of Educational Facility Planners.

Lewis, C.C., Schaps, E., \& Watson, M. S. (1996). The caring classroom's academic edge. Educational Leadership, 54, 16-21

Lowe, Jerry M. (1990). The Interface Between Educational Facilities and Learning Climate. Unpublished doctoral dissertation. College Station, TX: Texas A\&M University.

Lehtinen, E. (1997), Verkkopedagogiikka, Edita, Helsinki Lockheed, M., Vail, S., \& Fuller, B. (1986). How textbooks affect achievement in developing countries: Evidence from Thailand. Educational Evaluation and Policy Analysis, 8, 379- 392.

Lyons, J. (2001). Do schools facilities really impact a child's education? from http://www.coe.uga.edu

Lyons, J. B. (2002). The learning environment: Do school facilities really affect a child's education? Learning By Design, 11, 10-13.

Ma, X., \& MacMillan, R. B. (1999). Influences of workplace conditions on teachers' job satisfaction. Journal of Educational Research, 93, 39-47. Retrieved December 19, 2008, from ProQuest database.

McGuffey, C.W. And Brown, C.L. (1978) The impact of school building age on school achievement in Georgia. CEFPI Journal, 16, 6-9.

McGuffey, C.W. (1982). Facilities. In H.J. Walberg, Improving educational standards and productivity (pp. $237-$ 281). Berkley, California: University of Illinois.

Manninen, A. et al. (2007),Oppimistatukevat ympäristöt. Johdatus oppimisympäristöajatteluun, Opetushallitus, Helsinki

Maiden, J., \& Foreman, B. (1998). Cost, design and climate: Building a learning environment. School Business Affairs, 64(1), 40-44.

Manning, M. L., \& Saddlemire, R. (1996). Developing a sense of community in secondary schools. National Association of Secondary School Principals. NASSP Bulletin, 80(584), 41-48.

Maier, S. (2010). Assessing school climate using a sequential transformative design "Doctoral dissertation" Colorado State University.

Marshall, M. L. (2009). Examining school climate: Defining factors and educational influences. Retrieved February 3, 2009, from http://education.gsu.edu/schoolsafety/

Martens, D. (2005). Research Methods in Education and Psychology: Integrating Diversity with Quantitative Approaches. (2nd Ed).Thousand 0aks: Sage.

Maxwell, J. A. (2005). Qualitative research design: An interactive approach (2nd ed.). Califonia: Sage.

McEvoy, A., \& Welker, R. (2000). Antisocial behavior, academic failure, and school climate: A critical review. Journal of Emotional and Behavioral Disorders, 8(3), 130-140.

McGuffey, C. W. (1982). Facilities. In H. J. Walbert Improving Educational Standards and Productivity. Berkeley, CA: McCutchan.

McMillan, J. H., \& Schumacher, S. (2001). Research in education: A conceptual introduction (5 ${ }^{\text {th }}$ ed.). Wesley: Longman.

Merriam, S. B (2001). Qualitative research and case study applications in education. San Francisco: JosseyBass.

Moore, D. P., \& Warner, E. (1998, December). Where children learn: The effect of facilities on student achievement. CEFPI Issue Trak, 1-4.

Moore, K. J. (2008). Modern public school facilities: Investing in the future. Retrieved May6, 2010, from

http://www.cde.ca.gov/ls/fa/sf/documents/congresstestimony.doc

Murphy J., Weil, M., Hallinger, P., \& Mitman, A. (1985). School effectiveness: A conceptual framework. The Educational Forum, 49(3), 361-374.

Mulford, B., Kendall, D., Ewington, J., Edmounds, B.F., Kendall, 1., \& Silins, H.(2008). Successful principalship 
of High Performance Schools in a high-poverty communities (Electronic version). journal of Education Administration, 46(4), 461-480.Retrieved $\quad$ February $10, \quad 2009, \quad$ from www.emeraldinsight.com/101180/09578230810882009

Mutiu, B. (1994). Towards improvement of schools. Journal of Studies in Education, 4(1), 45-55.

Mugenda, O. \& A. Mugenda (1999). Research Methods: Quantitative and Qualitative Approaches. NRB ACTS.

Mononen-Aaltonen, M. (1998), “A Learning Environment - A Euphemism for Instruction or a Potential for Dialogue?",Media Education Publication 8, pp. 163-212.

Nuikkinen, K. (2009). Koulurakennus ja hyvinvointi. Teoriaa ja käyttäjän kokemuksia peruskouluarkkitehtuurista. Acta Universitatis Tamperensis 1398. Kasvatustieteiden laitos, Tampereen yliopisto, Tampere

Nacino-Brown, P., Oke, F. E., \& Brown, D. P. (1982). Curriculum and instruction: an introduction to methods of teaching. London: Macmillan Publishers.

Nachmias, G. \& Nachmias, D. (1996). Research Methods in Social Sciences. 5th Edition. Arnold, London.

Nicole, C. E. (2006). School Facilities and Student Achievement: Student's Perspectives on the Connection between the Urban Learning Environment and Student Motivation and Performance: A Dissertation: Ohio state university.

Nigaglioni, I. (2005). Thinking outside of the box: Educational Facility Planner; vol.40. Issue 3/4, p.3.

Nwachukwu, G.O. (1984). A survey of the resources for the teaching and learning of Biology in some new secondary schools in Lagos. Unpublished Ph.D Thesis, University of Ibadan, Ibadan

Walker, L.J. \& White, 1. J (1988). Working in Urban Schools. Washington, DC: Institute for Educational Leadership

O'Neill, D. (2000). The impact of school facilities on student achievement, behavior, attendance, and teacher turnover rate at selected Texas middle schools in Region XIII ESC. Unpublished doctoral dissertation, Texas A\&M University, College Station, TX.

O'Neill, D. J., \& Oates, A. (2001). The impact of school facilities on student achievement, behavior, attendance, and teacher turnover rate in Central Texas middle schools. Educational Facility Planner, 36(3), 14-22.

Organization for Economic Co-operation and Development. (2000). The appraisal of investments in educational facilities. Pembroke, MA: OCED.

Ortiz, F. I. (2002). Essential learning conditions for California youth: Educational facilities. Retrieved July 31 , 2008, from http://repositories.cdlib.org/idea/wws/wws-rr007-1002.

Odulaja, G. \& Ogunwemimo, K. (1989). Teachers Attitude Towards Biology Practical with Particular Reference to School certificate Biology practical Examinations. A case study of Lagos. B.Sc project Report, University of Lagos.

Overbaugh, B. L. (1990). School facilities: The relationship of the physical environment to teacher professionalism. (Doctoral dissertation, Texas A\& M University). Retrieved July 28, 2008, from ProQuest Digital Dissertation database. (AAT 9027259)

Oates, J. (2003). Critical conditions for equity and diversity in college access: Informing policy and monitoring results. Los Angles, CA: University of California.

Organization for Economic Co-operation and Development. (2000). The appraisal of investments in educational facilities. Pembroke, MA: OCED.

Okoli, A. (1995). Education: A year of disaster at all Levels. Vanguard, January 4, pp 12-13

Oni, J.O. (1992). Resource and resource utilization as correlates of school academic performance in the secondary pre-vocational education in Ogun-State Nigeria. Unpublished Ph.D thesis, Department of Educational Management, University of Ibadan.

Olutola, A. (1982). School planning and Maintenance Introduction to Educational Planning. S Adesina (ed). IleIfe University of Ife Ltd, p.210-219

Ola, J.R. (1990). The Place of School Library in the New 6-3.3-4 Educational System. Teachers Journal Ondo State ANCOPSS (2nd Ed), Ibadan, Evans Brothers Nigeria Publishers

Ogunniyi, M.B. (1983). Analysis of Laboratory Activities in Selected Nigerian Secondary Schools. European Journal and Science Education, Vol. 5, (2)

Opare, J. A. (1991). Academic achievement in private and public schools; Management makes the difference. Journal of Educational management, 2, 1- 12.

Owoeye, J.S. (1991). The effect of interaction of location, facilities and class size on academic students' achievement of secondary school students in Ekiti State, Nigeria. Unpublished PhD thesis, Department of Educational Management, University of Ibadan.

The Oxford Advanced Learners Dictionary (1998). Page 919; 5th Edition London: Oxford Press.

Patton, M. (1990). Qualitative Evaluation and Research Methods (2nd Edition). Newbury Park, CA: Sage Publications, Inc. 
Paredes, V. (1991). School Climate and Student Achievement. Executive Summary. Austin Independent School District, Tex. Office of Research and Evaluation.

Paton, G. (2005). Ferrari facilities don't raise standards. Times Educational Supplement: October 10, issue 4658, p. 18.

Peretemode, V. F. (2001). Educational Administration: Applied Concepts and Theoretical Perspective. Lagos: Joja Educational Research and Publishers Ltd.

Popoola, T. A. (1989). An Investigation between Instructional Resources and Academic Performance. Unpublished M.ED Project, University of Ilorin

Phillips, R. W. (1997). Educational Facility Age and the Academic Achievement of Upper Elementary School Students. Unpublished Doctoral Dissertation. University of Georgia.

Quddus, N.J. (1990). Problems of Education in Pakistan. Karachi: Royal Book Company.

Quinn, D. M. (2002). The impact of principal leadership behaviour on instructional practice and students engagement (Electronic version). Journal of educational administration,40,5,447-467.RetrievedJuly2008, from www.emeraldinsight.com/

Rivera-Batiz, Francisco L., and Lillian Marti (1995). A School System at Risk: A Study of the Consequences of Overcrowding in New York City Public Schools. New York: Institute for Urban and Minority Education, Teachers College, Columbia University.

Randall, D., Fedor, D., \& Longenecker, C. (1990). The behavioral expression of organizational commitment. Journal of Vocational Behavior, 36, 210-224.

Rebore, R. W., \& Stollenwerk, D. A. (2001). The ethics of educational leadership.

Rosenholtz, S. L., \& Simpson, C. (1990). Workplace conditions and the rise and fall of teachers' commitment. Sociology of Education, 63, 241-247.

Rouk, U. (1997). PROBE-developing education policy issues. Washington, DC: National Education Knowledge Industry Association Communications.

Ryozo, L., Yasuahi, M., Takaharu, M. \& Jiro, N. (1981). Multi Media Instructional Materials and Social Studies. UNESCO handbook for the teaching of social studies. (Ed) Mehlinger, H.D., London: groom helm.

Sanoff, H. (2001). School building assessment methods. Retrieved December 3, 2008, from $\mathrm{http}: / /$ www.edfacilities.org/rl/facility_assessment.cfm

Schneider, M. (2002). Do school facilities affect academic outcomes? Washington, DC: National Clearinghouse for Educational Facilities. From http://www.edfacilities.org/pubs/outcomes.pdf

Simon, N. S., Evans, G. W., \& Maxwell, L. E. (2007). Building Quality, Academic Achievement and SelfCompetency. Lausanne: New York City

Smith, T. E. C. (1984). Opening doors: American School and University, 56(6), 64-65.

Smith, P. A. \& Holy, W.K (2007).Academic optimism and students achievement in urban Elementary schools (Electronic version).Journal of Education Administration, 45(5), 556-568. Retrieved February 10, 2008, from emeraldinsigth.com/10.1108/09578230710778196

Smith, W .and Andrews .R. (1989). Instructional Leadership; how principals make a Difference. Alexandra: .A. Association for supervision and curriculum Development.

Snow, S. E. (2002). Teachers Perceptions and use of Classroom Space. Athens, George. This work looks at perceptions of secondary school teachers on the use of the class room space, in Georgia in the U.S.A

Stake, R. (1978). The Case Study Method in Social Inquiry. Educational Research, 7(2),5.

Stake, R. (1999). The Goods on American Education. Phi Delta Kappan: May, vol. 80, p. 668-672. 8.

Steinar, K. (1996). Interviews: An Introduction to Qualitative Research Interviewing. Sage Publications: London.

Strauss, A. and Corbin, J. (1990). Basics of Qualitative Research: Grounded Theory Procedures and Techniques. Newbury Park, CA: Sage Publications Inc.

Squire, J. R. (1991). Textbook Publishing in Encyclopaedia of Educational Research, Vol. 4 (6th Edition), Macmillan, pp. 1419.

Shodimu, G.O. (1998). Resource Availability, Utilization and Productivity in Public And Private Secondary Schools in Lagos State; A Ph.D seminar paper, University of Lagos.

Soyibo, A. \& Nyang, G.O.E (1990). An Analysis of the school certificate Biology result of old and new Secondary School in Cross Rivers State 1978-1982. Nigeria Education forum 7(2),245-250.

Rein, A. S. (1997). The State of Municipal Services in the 1990s: Crowding Building Conditions and Staffing in New York Public Schools. Citizens Budget Commission, New York, NY.

Tan, J. P., Lane, J., \& Coustere, P. (1997). Putting inputs to work in elementary schools: What can be done in the Philippines?. Economic development and cultural change, 45(4), 857-879

Tamakloe, E. M., Amadahe, F. K., Atta, E. T. (1996). Principles and Methods of Teaching, Accra; Black Mask Ltd.

Taylor, A. \& Gousie, G. (1988). The ecology of learning environments for children. CEFPI Journal, 26(4), 23-28. United Nations Educational, Scientific, and Cultural Organization. (2008). Historical context of school buildings 
and facilities program. Retrieve May 2, 2008, from http://www.unesco.org

Uline, C. L., Tschannen-Moran, M., \& Wolsey, T. D. (2008). The walls still speak: The stories occupants tell. Retrieved December 2, 2008, from http://edweb.sdsu.edu/schoolhouse/C/stories.pdf

Vision, G. (1996). 2020 Document (1996). The first step, 2020.

Van Roekel, D. (2008). Economic impact of school infrastructure investments. Retrieved December 2, 2008 , from http://waysandmeans.house.gov/hearings.asp?

Vincent, J., \& Filardo, M. (2008). Linking school construction investments to equity, smart growth, and healthy communities. Berkeley CA: Center for Cities \& Schools at University of California-Berkeley.

Wanzare , Z \& Ward, K.L. (2000). Rethinking staff development in Kenya: Agenda for the twenty first century (Elective vision). The international journal of Educational Management, 14(6), 265-275. Retrieved February 13, 2009, from www.emeraldinsight.com/0951-354X.htm.

Williams, T.D. (1973). Efficiency of Education in Education and National Building in the Third World,

Yadar, k. (1982) Teaching of life Science, New Delhi, Anmol Publications. Ltd. India.

Yonezawa, S., Jones, M., Mehan, H., \& McClure, L. (2008). School climate and student achievement. Retrieved February 20, 2009, from http://www.closingtheachievementgap.org

Zepeda, S.J.(2003). The principal as instructional leader: A hand book for supervisors. Larchmount, NY: Eye on Education. 